Izvorni članak UDK 17(091)(38)"-04"

doi: $10.21464 /$ fi36103 Primljeno 11. 12. 2015 .

\author{
Milenko A. Perović \\ Univerzitet u Novom Sadu, Filozofski fakultet, Dr Zorana Đinđića 2, RS-21000 Novi Sad \\ perovic@ff.uns.ac.rs
}

\title{
Sofistička proto-etika
}

\begin{abstract}
Sažetak
U identificiranju nastanka moralno-etičkog fenomena, autor polazi od uvjerenja da je on povijesnog, a ne »vječnog« karaktera. Rudimentarni oblik autor nalazi u proto-moralnoj svijesti i proto-etičkom filozofskom stajalištu sofista. U osloncu na Aristotela i Hegela, rekonstruira helenski običajnosni sustav djelatnog života i pokazuje temeljni smisao povijesnog obrata što ga sofisti u tom sustavu provode svojom filozofskom i kulturnom misijom. $U$ tome se obratu rađa moralno-etički fenomen kao učinak sofističkog konfrontiranja razumskog (razložnog) mišljenja tradicijskoj predodžbenoj svijesti.
\end{abstract}

Ključne riječi

sofisti, običajnost, moral, etika, predodžba, razum, razložnost

Aristotel je filozofski razvio pojmovnu strukturu ethos-hexis-êthos ispitivanjem djelovanja (praxis) u klasičnom helenskom polisu. Velike heurističke mogućnosti njegova uvida posvjedočuju se u praktičkoj filozofiji, posebno u razumijevanju pred-povijesti i povijesti moralno-etičkog fenomena, a naročito u dokučivanju smisla sofističke i Sokratove filozofije kao filozofskih događaja svjetsko-povijesne vrijednosti u kojima se odvija transformacija običajnosnog u moralni način djelovanja. Hegelu se ima zahvaliti na pojmovnoj refleksiji helenske običajnosti. U složenoj komparacijskoj strukturi odnosa s poviješću moralnog praksisa, te modernom građanskom običajnošću, Hegel je dokučio organski sklop djelovanja predsokratske Helade na temelju uvida da običaj (ethos) čini glavni oblik djelovanja ljudi i zajednice, a sustav običaja (običajnost) sklop uljuđivanja čovjeka u uljuđenoj zajednici. Aristotelove i Hegelove postavke naveliko pomažu u dokučivanju smisla i načina transformacije helenske običajnosti u moralno-etički fenomen.

Sustav običajnosti je organski oblik uređenja djelatne zajednice ljudi. Način nastajanja, trajanja i regulacije djelovanja, način važenja običaja kao normi djelovanja, te legitimacija običaja dolaze od moći tradiranja koja se generacijski prenosi s uvjerenjem predodžbene djelatne svijesti - da je čvrstina držanja pri običajima uzus postojanja uljuđene zajednice. Karakter (ēthos) čovjeka - kultiviran navikom (ethos) i ustaljen (hexis) u svojim djelatnim stavovima, na temelju »interioriziranja « važećih običaja (ethos) - eficijentni je element prenošenja i održavanja duha zajednica utemeljenih na običajnosnom sustavu djelovanja. Djelatne svrhe ljudi u njemu dobivaju smisao iz uklopljenosti u sustav običajnosnih svrha. Pojedinac u običajnosnoj zajednici je - »upojedinjena « cjelina običajnosti! On je sustav običaja »u malom《 jer se običajnost »individuira « u pojedincu i stvara ljudski karakter (êthos). Običajnost se odr- 
žava individuiranjem u karakterima. Oni se povratno održavaju u toj moći, održavajući njenu snagu važenja.

Pojmovna struktura ethos-hexis-ēthos opisuje »individuiranje« običajnosnog duha u pojedinačnom karakteru čovjeka. Istina, u Aristotelovom pojmu ethos nerazdijeljeno je značenje pojma ethos kao običaja i ethos kao navike. Običaj je socijalna navika. Navika je običaj pojedinca! Aristotel reflektira djelatni svijet u kome razlika između kolektivnog i »individualnog« djelovanja još nije napredovala do suprotnosti i opreke. Neće se iznevjeriti duh Aristotelova poimanja djelatnih stvari ako se opći sklop važenja običaja shvati kao - opći ethos. U Aristotelovom topičkom smislu njegovo je postojanje samorazumljivo. ${ }^{1}$ Topika pomaže u pojmovnom rekonstruiranju helenske običajnosti. Helenska mitologija počiva na ideji ciklizma. Helenska civilizacija sebe promatra u cikličkom temporalnom kretanju. Helenska filozofija u svom središtu ima ideju ciklizma. Cikličko je i helensko običajnosno predočivanje i filozofsko poimanje ljudskog djelovanja. Običajnosno djelovanje ima kružni karakter: opći ethos-ethos-hexis-ēthos. Bez napetosti, opći ethos ozbiljuje se konkretnim običajima i odgojem ljudi da ih slijede u djelovanju. Pred-sokratska Helada ne poznaje niti podvojenost između privatnog i javnog niti između običaja (ethos) i karaktera (ēthos). »Interiorizirani« običajnosni sustav u njoj se ozbiljavao kao karakter čovjeka. Duh toga sustava nije mogao biti niti neispoljen niti sabijen u ljudskoj unutrašnjosti. Očitovao se u zajednici. Štoviše, činio je zajednicu! Karakter čovjeka očitovao se djelovanjem u domaćinstvu (supružništvo, roditeljstvo i ekonomski život), prijateljstvu (u »neformalnoj« druževnosti kao obliku društvenosti) i polisu (u kome je pojedinac mogao obavljati niz različitih javnih dužnosti). Karakter čovjeka rađao se na agori. Živio je na agori i za agoru!

Moral kao oblik ljudskog djelovanja (praxis) nije »vječni«, nego je povijesni fenomen. Heleni su prvi među starim narodima razobručili ideju ciklizma običajnosnog načina djelatnog života i dali mu lik slobodnog pojedinca u slobodnom domaćinstvu koji uživa slobodno građanstvo. U korijenu toga obrata, od svjetsko-povijesnog značaja nalazilo se otkriće slobodne refleksije na djelovanje. Najprije se ona javila kao povratna svijest čovjeka o onome što čini, što mu je svrha i orijentir djelovanja. Rudimenti povratne svijesti o djelovanju postojali su i u običajnosnom sistemu djelovanja. Sustav običajnosti u Helena još od »homerovske epohe« pokazivao je fronetičku kulturu u oblicima djelatnog života (predodžbe o dobru i zlu, vrlini, valjanom uređenju polisa itd.), u nomotetičkoj kulturi, kao i pred-političkim institucijama. Od Homera i Hesioda teče proces jačanja ljudske djelatne samosvijesti. Njen vodeći oblik je običajnosna razboritost (phronesis). Ona stvara, ispituje i mijenja ethos i nomos. Granica običajnosne djelatne povratne svijesti je razboritost koja ne ispituje samu sebe! Običajnosna phronesis stvara vlastiti sadržaj, ali ne ispituje sebe kao duhovnu moć koja tom sadržaju daje formu. Ona još nije spremna da samu sebe uzme za predmet ispitivanja jer nije svjesna sebe kao samosvijesti djelovanja.

Fronetička svijest stvara običajnosni sustav djelovanja. U njemu ono opće (polis kao zajednica) ima moć nad posebnim (domaćinstva u polisu) i pojedinačnim (ljudi u domaćinstvima i polisu). Moć općega je moć zajedničkog nad partikularnim. Domaćinstvo nema pravo na interese koji ne bi bili u skladu $\mathrm{s}$ interesima polisa. Pojedinac nema pravo na interese koji su suprotni interesima domaćinstva i polisa. Posebne ljudske strane života odstupaju pred vrijednošću općih poslova (državništvo, zakonodavna djelatnost, sudačka djelatnost, vojskovodstvo i ratni posao, državni »javni radovi«, ekonomsko i 
financijsko poslovanje polisa, javna odgojna djelatnost, graditeljstvo, umjetnost, javne zabave, religijski rituali i svetkovine, vanjska politika itd.). U povijesti pred-sokratske Helade, odnos općeg, posebnog i pojedinačnog u polisu nije bivao bez unutrašnjih potresa, nestabilnosti i narušavanja. No uvijek je ostajao neupitnim sâmi sustav običajnosti.

Kako objasniti nastajanje dubljih disharmonija u helenskom sustavu običajnosti? Kako je mogla nastati potreba za slobodnim pojedincem koji odbija mjerila djelovanja običajnosnog sustava i nova mjerila traži u sebi? Rasprostranjeno je objašnjenje među povjesničarima filozofije i etike da je to djelo sofističke skepse i Sokratove filozofije. Ipak, u njemu se obrće zbiljski smjer kauzalnog djelovanja između krizne disharmonije sistema običajnosti i sofističko-sokratskog mišljenja. Djelatnost sofista i Sokrata dala je disharmoniji posebni karakter, ali filozofija nema moć izazivanja društvenih i svjetonazorskih kriza. Krize se misaono najjasnije odražavaju u filozofiji. Sofistička i Sokratova filozofija reflektiraju duhovnu i funkcijsku krizu klasičnog helenskog polisa, a nisu njezin uzrok. Njihova je refleksija, istina, dijelom uvjetovala smjer oblikovanja krize u nastajanju morala i njegovog etičkog promišljanja, ali na jedan paradoksalni način!

Povjesničarima filozofije i etike obično manjka spekulativne misaone supstancije pa nisu u stanju dokučiti da su moral kao oblik djelovanja i etika kao njegova filozofska refleksija djelo - paradoksa! Sofisti i Sokrat poduzeli su misaono ispitivanje predodžbenog načina mišljenja ljudske djelatne svijesti. Na samoniklom predodžbenom mišljenju - koje sebe ne reflektira na kritički način - počivao je običajnosni sustav djelovanja u Helena. ${ }^{2}$ Sofisti i Sokrat smatrali su da se kriza običajnosnog sustava djelovanja može prevladati ako se predodžbeno mišljenje osnaži razumskim, odnosno umskim mišljenjem. Sofisti su osnaživanje shvatili kao poticanje razložne (razumske), a Sokrat kao poticanje pojmovne svijesti. Međutim, predodžbenu svijest to ne može učiniti pouzdanijom. Naprotiv, izložena sofističkoj razumskoj (razložnoj) ili Sokratovoj umskoj (pojmovnoj) samorefleksiji, ona postaje još konfuznija i nepouzdanija! Helenska svjedočanstva o djelovanju sofista i Sokrata kazuju kako se slama predodžbena svijest, općenito - predodžbeni način mišljenja. Sofisti i Sokrat htjeli su obraniti običajnosni sustav djelovanja. Svojim su obranama, naprotiv, potkopali njegove temelje.

1

Bitni dio Aristotelove topike su topoi (plur. prema grč. $\tau o ́ \pi o s: ~ t o p o s ;$ prema lat. locus communis, plur. loci: mjesta), tj. stavovi u kojima se radi o praktičkim uputama, logičkim zakonomjernostima ili pravilima na koje mora paziti diskutant da bi vodio valjani disput. Aristotelovi topoi ponajviše se odnose na djelovanje (praxis) u helenskom običajnosnom sustavu. Njegov sistematski duh ipak nije mogao - nije to dopuštala priroda spontanog nastajanja predodžbi o djelovanju - izbjeći činjenicu da praktički topoi međusobno stoje u odnosima manje ili veće napetosti. Oni pokazuju da su među Helenima postojale brojne osviještene $\mathrm{i}$ neosviještene razlike $\mathrm{u}$ mišljenjima o mnogim stvarima vezanim za djelovanje. Topoi pokazuju da su Heleni različito mislili o djelatnom dobru, blaženstvu, kreposti, hotimičnosti itd. Različito su mislili i o najboljem uređenju polisa, o upravljanju robovima, o odnosu prema metecima itd. Topoi su dokaz životne dinamičke napetosti u helenskom običajnosnom duhu.

2

Znatno prije sofista i Sokrata postojala je određena sumnja u vrijednost predodžbenog načina mišljenja u običajnosnom sustavu. Plutarh je zabilježio anegdotu o skitskom mudracu Anaharsisu i Solonu koji je položio nomotetičke temelje atenske običajnosti. Anaharsis ('Avó $\chi \alpha \rho \sigma ı$, oko 605.-545. god. pr. n. e.) se smijao Solonovim zakonima: »Takve riječi ni po čemu se ne razlikuju od paukove mreže; istina, one će zadržati samo slabe i male koji se uhvate, ali moćni i bogati će ih razderati!« Solon mu je odgovorio da je zakone prilagodio građanskom životu, tako da će svako uvidjeti koliko je bolje postupati po zakonima, negoli ih gaziti. 
Sumnja sofista u vrijednost predodžbenog mišljenja pogodila je samorazumljivo važenje staroga ethosa i nomosa. Nije njihova sumnja bila usmjerena protiv njihova sadržaja. Pogađala im je legitimacijsku osnovu ${ }^{3}$ kao samorazumljivost i neupitnost važenja ne ovoga ili onoga običaja i zakona, nego načina mišljenja koji običajima i zakonima pribavlja pravo na važenje. Sofisti su osporili pravo na neupitno važenje predodžbenog mišljenja kao takvog! Osporili su vodeći način postojanja običajnosnog sustava. Predodžbeno mišljenje je pribavljalo snagu važenja svakom svojem predodžbenom sadržaju. Konkretni nomos i ethos - kao djelo neupitnog mišljenja - bili su neupitni. Legitimacija običajnosnog sustava ne trpi sumnju. Sofisti su osporili shvaćanje da nomos i ethos dobivaju legitimnost iz naturalnog ili supra-naturalnog poretka zbiljnosti. Izveli su zaključak: nomos i ethos su ljudske postavke.

Posljedice njihova skeptičko-kritičkog stava su brojne. Prvo: suprotnost između prirode (physis) i zakona (nomos i ethos) ne može se prevladati niti mitološkim niti predodžbenim mišljenjem, kao ni posebnom zakonodavnom (nomotetičkom) djelatnošću. Tradicija mitologije, nomotetike i prevlasti predodžbenog mišljenja je i dovela običajnosni sustav do legitimiranosti koja iznevjerava. Drugo: iznevjerena je moć predodžbenog mišljenja. Prevladavanje suprotnosti physis-nomos ne može se više postići predodžbenim mišljenjem, nego samo razumom. Da bi se spasio od kaosa i propasti, običajnosni sustav mora biti osnažen razumskim mišljenjem. Samo ono može prevladati opreku physis-nomos i običajnosnom sustavu pribaviti novu razumsku legitimaciju. Treće: u običajnosnom djelovanju ne može se postizati apodiktička izvjesnost. U filozofiji je misao o logosu vječnih stvari počivala na neizrečenoj pretpostavci mogućnosti postizanja apodiktičkih spoznaja. Nestalnosti u ljudskom praksisu nisu mogle ohrabrivati htijenje takve spoznaje. Tražeći zakonomjernosti u praksisu, sofisti su otkrili posebni tip razumskog mišljenja. Otkrili su razumnost kao razložnost. Bili su uvjereni da je razložnost imanentna ljudskom djelovanju. Utoliko, djelovanje je moguće spoznavati i reglementirati! Razložnost je rezonirajuće mišljenje koje rasuđuje i zaključuje otkrivanjem razloga. Sofisti su otkrili razlog kao logos (misaonost) djelovanja. Četvrto: helenska kozmologija je bitak bića ispitivala kao odnos uzrok-posljedica (učinak). Sofisti su razumjeli da se ontološka specifičnost praksisa mora tražili izvan odnosa uzrok-posljedica. Kauzalnost praksisa razumjeli su kao odnos razlog-posljedica (učinak). Peto: kako i gdje dokučiti razloge kao sigurne oslonce djelovanja? Djelovanje počiva na ljudskim djelatnim (praktičkim) svrhama. Sofisti su pošli od uvjerenja da kriza običajnosnog sustava dolazi od poremećaja koji izaziva predodžbena svijest svojim određenjima djelatnih svrha. Ta svijest svaku partikularnu svrhu može uzeti kao opću svrhu. Samo u rudimentarnom obliku u njoj se može začeti misao o potrebi posredovanja svrha. Običajnosna zajednica još nema senzibilitet za takvu potrebu. U njoj djelatne svrhe važe silom socijalne inercije. Šesto: običajnosni sustav mora biti učinjen razložnim. Mora moći racionalno posredovati pojedinačne, posebne i opće svrhe ljudi u zajednici. Kriza običajnosnog sustava nastaje kada stari načini spontanog posredovanja djelatnih svrha više ne zadovoljavaju. To stanje vodi slabljenju i gubljenju mehanizama izbjegavanja sukoba svrha (interesa) u helenskim polisima.

\section{Sofistička priprema moralnog stava}

Sofisti postuliraju racionalno posredovanje djelatnih svrha. Ta je postulacija smislena samo uz pretpostavku radikalnog obrata u antropologijskoj samorefleksiji. Bit obrata je u spoznaji da posredovanje može zavisiti od čovjeka, od 
ljudskih mjerila, od samoga čovjeka kao mjerača i mjerila! Čovjek to može biti po svojoj razložnoj svijesti. Ona otkriva racionalne i prihvatljive razloge djelovanja. Sofisti su držali da se tako može postići sigurnost pojedinca $i$ zajednice u djelovanju. Tako trasiraju put nastanku morala kao posebnog oblika djelovanja i razlaganju običajnosnog sustava. Pojava morala usko je povezana s bitnim teškoćama u sofističkom stavu. One su nastale iz njihovog uvjerenja da razložna svijest djelovanju može pružiti sigurne osnove. Uistinu, ona je izazvala još veću dezorijentaciju u djelovanju, a sofističku filozofiju iznijela na loš glas. Misao o čovjeku kao mjerilu implicirala je da se gubitak ljudskog pouzdanja u vanjska mjerila djelovanja može nadomjestiti okretanjem razložnoj svijesti kao unutrašnjem mjerilu i pokretaču djelovanja. No unutrašnjost čovjeka čine i osjećaji, osjećanja, predodžbe, nagoni, strasti, htijenja, nagnuća itd. Svaka od tih moći može htjeti biti tvorcem djelatnih svrha i pokretati na djelovanje. Sve su one - čovjekove, a čovjek je mjera! Svaka može biti mjera djelovanja. Razložna svijest može opravdavati, ali i opovrgavati pravo na zadovoljenje svakog interesa (svrhe). Razložna svijest nema moć dokučivanja dodatnog mjerila za utvrđivanje koji su interesi (svrhe) opravdani! Zato što je razložna, ta svijest može svakom unutrašnjem duševnom poticaju za djelovanje priznati vrijednost i pronaći mu odgovarajući razlog. Svaki razlog, jednako, može odbaciti i naći mu protu-razlog. Razložna svijest može istu stvar dokazivati kao dobru ili lošu, valjanu ili poročnu, pravednu ili nepravednu itd. Kao mjerilo djelovanja, ona izaziva gubljenje svakoga mjerila. Tako se ne učvršćuje, nego razara temelj uređene ljudske zajednice. Zahvaljujući Sokratovoj, Aristofanovoj, Platonovoj i Aristotelovoj kritici sofista, Heleni su razumjeli kakvu subverzivnu moć ima sofističko otkriće razložne svijesti - ona može opravdavati sve moguće svrhe, pa i one neljudske.

Osporavajući legitimnost običajnosnog sustava djelovanja, sofisti su otvorili pitanje potrebe racionalnog legitimiranja svakog sustava djelovanja, što do danas okupira praktičku filozofiju i sve posebne znanosti o ljudskom djelovanju. Sofisti su to pitanje izveli iz uvida u suprotnost physis-nomos. Idejom prirodnog prava mislili su riješiti problem legitimnosti djelovanja na temelju uvjerenja da je priroda pouzdano mjerilo ethosa i nomosa. U formalnom smislu, razložna svijest predodžbu o legitimnosti crpi iz ideje prirode, prirodnog zakona ili prirodnog prava. Kada pak treba sadržajno odrediti što je priroda, razložna svijest pokazuje se kao aporetična. U razmatranju valjanosti konkretnih svrha djelovanja, svaku svrhu može opravdati razlogom ili odbaciti protu-razlogom. Na isti način postupa kada sudi o sadržaju onoga što je "po prirodi« (po »prirodnom pravu« ili »prirodnom zakonu«). Svaku svrhu ona može opravdati ili odbaciti postavkom da je »po prirodi« ili »protiv prirode«. Sofisti tako rješavaju i problem jednakosti ljudi. Hipija tvrdi da su ljudi jednaki »po prirodi« (»po rođenju«). Trazimah i Kalikle tvrde suprotno: prirodno je pravo da jači vlada nad slabijim!

Kakve posljedice po običajnosni sustav ima aporetičnost sofističke razložne svijesti? Sofisti kane obraniti taj sustav, ali mu ugrožavaju temelje jer razaraju običajnosni predodžbeni način mišljenja. Nagovarajući Helene na razložno mišljenje, udaraju protiv načina samoodržanja običajnosnog sustava. Sustav je nekolika stoljeća trajao u kružnom karakteru: opći ethos-ethos-hexis-èthos. Kružno kretanje djelatnog života Helena generacijski se opredmećivalo u pojedinačnim ljudskim karakterima (êthos). Svrha djelovanja karaktera bila je 
održanje općeg ethosa. Sofisti narušavaju kružni oblik sustava djelovanja. Njegovo ishodište i težište premještaju s općeg ethosa na etthos. Ako je čovjek mjerilo svega - pa i djelovanja - individua mora moći najbolje znati što je za nju dobro i kako će djelovati. Čovjek kao individua može to znati ako razvija i upotrebljava svoju razložnu svijest. Narušavanjem važenja i razobručivanjem kružnog sustava djelovanja i premještanjem njegova težišta na racionalnost èthosa sofisti su anticipirali nastanak morala kao posebnog oblika djelovanja!

Što je neposredna posljedica te anticipacije? U običajnosnom sustavu, karakteri ljudi bili su djelo moći samoodržanja sustava. Skladni sustav djelovanja odgajao je skladne ljudske karaktere. U helenskim polisima - kao u svakoj organskoj ljudskoj zajednici - vladao je duh zajedništva i jednodušnosti. Opredmećivan je taj duh u osjećaju sudbinske pripadnosti čovjeka vlastitoj zajednici koja daje osnovni smisao njihovom životu. Pojava krizne napetosti u sustavu morala je izazivati napetost u samim ljudskim karakterima. Dvostrukost napetosti učinila je Heladu prijemčivom za djelatnost sofista. Nagovor sofista na razložnu svijest - kao način postizanja reflektiranog sklada u zajednici i sklada čovjeka sa sobom i drugim ljudima - u društvenoj i duhovnoj zbiljnosti proizveo je suprotno djelovanje! Ohrabren mogućnošću opravdanja svih svrha koju pruža razložna svijest, svako je mogao isticati »osobne« razloge za djelovanje, bez obzira na unutrašnje poticaje i interese. U polisu je svaka društvena grupa mogla držati svoje interese za najopravdanije i razložno ih dokazivati. Moć razložne svijesti tako je počela krnjiti duh zajedništva i jednodušnosti u polisima. ${ }^{4}$

Gubljenjem jedinstvenog duha morala se izgubiti integrirajuća snaga društvenog djelovanja. U običajnosnom sustavu ona je držala »na okupu« individualno, ekonomsko, pravno i političko djelovanje, tj. njihove rudimente. Sofisti su doprinijeli da ta snaga oslabi. Razlike između predočenih oblika djelovanja mogle su se stoga razviti do opreke. Opreka u običajnosnoj svijesti - koju su istakli i potaknuli sofisti - rodila je moralnu svijest kao novi način držanja čovjeka u djelovanju. Sofističko traženje racionalnosti u djelovanju postavilo je rudiment morala. Njihovo traganje za racionalnošću u djelovanju rudiment je etike i praktičke filozofije u cjelini. Jednom pokrenutu, silu racionalnosti običajnosni sustav više nije mogao suzbiti ni stigmatiziranjem sofista.

Sofisti su istakli pravo na slobodu subjektivne svijesti. Potakli su pouzdanje da ona sama u sebi može naći mjerilo djelovanja i svoj životni smisao. Postulirali su ono razložno - epistemičko (refleksivno i samorefleksivno) - kao novu antropološku osnovu djelovanja i njegove legitimnosti. Postavkom epistemičke subjektivnosti - u kojoj se konkretizira stav o čovjeku kao mjeri svih stvari - težište spoznaje i djelovanja premjestili su s običajnosne ustaljenosti (opći ethos) na spoznaju i karakter pojedinca (ēthos). Odlučujućom instancijom ljudskosti u čovjeku postala je razložna svijest kao tvorac oprečnih odredbi o stvarima djelovanja.

\section{Proto-etički stav sofista}

Polemički pojam probabilizma - koji izražava bitnu teškoću u sofističkoj odredbi razložne svijesti kao moći stjecanja znanje o djelovanju - pokazuje da su sofisti prvi iskusili teškoću koja je imanentna djelovanju kao takvom. Spontano su dokučili da se u djelovanju ne može postići sigurnost znanja kao u teorijskoj spoznaji jer djelovanje ima drugačiji ontološki karakter od fizikalne zbiljnosti. Čovjek je princip djelovanja. Sofisti su došli do te spoznaje 
i donijeli svijest da je djelovanje čovjekov životni i misaoni problem. Djelovanje je postalo životnim i filozofskim problemom zato što su sofisti razumjeli da ono bitno zavisi od svijesti, volje, htijenja i interesa čovjeka. Shvativši čovjeka kao mjerilo djelovanja, sofisti su pripremili misaoni put za Platonovo pitanje: Kako treba živjeti?

U tome pitanju događa se radikalni otklon od samorazumljivosti uvjerenja da ljudskim životom gospodare sudbina, bogovi i priroda. Kada je sumnjom uzdrmana njegova naviknutost da naprosto živi, čovjek se počinje pitati o vlastitom životu. Sumnja ga goni da tematski misli smisao vlastitog života. Helenski običajnosni čovjek spontano je lijepim životnim oblicima od svijeta načinio svoj zavičaj. Sofisti su pokrenuli svijest Helena da je smisao ono što je proizvedeno od samog čovjeka! No ako se može proizvoditi, smisao se može i izgubiti. U čovjeku je njegovo mjerilo i mogućnost promjene. Smisao djelatnog življenja i sigurnog znanja o njemu sofisti su učinili filozofskim problemom. Traženjem sigurnog djelatnog znanja otvorili su novu perspektivu samorefleksije čovjeka. Ona će utjecati na vodeći tijek zapadne civilizacije u zahtjevu za racionalnošću djelovanja i racionalnošću promišljanja te racionalnosti. Prvi zahtjev vodio je nastanku morala, drugi nastanku etike. Oba zahtjeva su inicirala nastanak drugih oblika djelovanja te filozofske refleksije djelovanja. Duh, koji je stvorio moralnu svijest, jednako je stvorio političku svijest, pravnu svijest i ekonomsku svijest. Rađanjem morala stvorene su pretpostavke rađanju drugih oblika djelovanja: politike, ekonomije i prava. Zametanjem filozofske refleksije djelovanja kao etike stvorene su pretpostavke rađanju filozofske refleksije politike, prava i ekonomije. Implicite, sofisti su položili temelje filozofiji politike, filozofiji ekonomije i filozofiji prava.

Sofisti su prvi problematizirali krizu običajnosnog sustava Helena. Protumačili su je kao posljedicu nesklada u sustavu djelovanja između prirodnog poretka stvari - koji bi trebao biti uzor ljudskom djelovanju - te postojećih helenskih predodžbi, institucija, običaja i zakona. Pitanje o porijeklu, karakteru i prevladavanju nesklada dovelo ih je do tematskog filozofskog ispitivanja ljudskog djelovanja (praxis). U njemu je vodećim postalo pitanje o ontološkom statusu ljudskog djelovanja. Iz njega je izvedeno pitanje o legitimnosti institucija polisa i važećih građanskih zakona i običaja. Ono je, nadalje, vodilo pitanju o valjanim načinima i oblicima djelovanja. Sofisti su anticipirali filozofsko razmatranje djelovanja prema njegovim oblicima: djelovanje pojedinca, djelovanje u domaćinstvu, zakonodavno (nomotetsko) djelovanje, kao i političko djelovanje.

Filozofija od početka živi u sukobu s predodžbenim nekritičkim mišljenjem. U tome se korijeni i nužnost sukoba između sofističke filozofije i običnih predodžbi Helena o djelovanju. Te predodžbe Heleni su izvodili iz sustava kulture oslonjenog na neupitnost važenja običaja, tj. »otačkih zakona« ( $p a-$ trios nómos). Kultura arhajske Helade u tome je bila srodna drugim starim kulturama. Sofisti su smjelo osporili neupitnost važenja konkretnih običaja i načina mišljenja koji producira i čuva to važenje. Filozofsko mišljenje oni usmjeravaju na pitanje o djelovanju te prenose težište misaonog interesa $\mathrm{s}$ kozmoloških pitanja na pitanja o čovjeku. Pretpostavku toga obrtanja valja

Tukidid u Povijesti peloponeskog rata pripovijeda kako se u atensku vojsku uvukao duh rasprave koju su Atenjani naučili od sofista. Pretvorivši se u skupinu »polemičara«, atenska vojska izgubila je jedinstvo volje. Svaki vojnik u njoj osjetio se »sposobnim da sudi« o umijeću vojskovodstva. Jedan od atenskih stratega prekorio je svoje vojnike da više liče na »posjedale slušače sofista«, nego na uređenu vojsku. 
tražiti u snaženju uvjerenja da se djelovanje može filozofski misliti. Odbili su obične predodžbe te djelovanje pokušali razumjeti kao razumno djelovanje.

Razumnost djelovanja je moć htijenja da se uspostavi vlast razuma nad nagonima. Omogućuje da, dokučivanjem razumnih svrha i sredstava djelovanja, čovjek na prihvatljiv način zadovoljava svoje interese, potrebe i nagone. Sofisti su shvatili da spontana fronetičnost običajnosne predodžbene svijesti vodi običajnosni sustav djelovanja u krizu jer njezine predodžbe važe na neobrazloženi način. One nisu plod kritičkih razumskih razmišljanja, nego su spontane ljudske postavke. Ozbiljene u običajima kao normama djelovanja, te predodžbe moraju biti obrazložene! Sofistički zahtjev inicira veliki obrat u cjelini helenske kulture jer je usmjeren protiv ustaljenog običajnosnog načina mišljenja. Obrazloženost djelovanja je razumnost djelovanja! Sofisti su razumsko mišljenje shvatili u prvom redu kao razložno mišljenje, rezoniranje (prema franc. raisonnement). Kao moć mišljenja da razloži mišljenu stvar, razložnost se pokazuje kao analitička funkcija razuma. Kada mišljenju razloži stvar na sastavne dijelove, razložnost ujedno odlučuje koji od njih će uzeti kao bit stvari. Odluku ozbiljuje kao postavku (thesis), tj. tvrdnju o biti stvari. No i drugi se dijelovi jednako mogu smatrati njenom biti. Stoga, svaka postavka može biti prihvaćena ili osporena. Razložno mišljenje pred sebe postavlja zahtjev za dokazivanjem postavke koherentnim i metodičnim navođenjem argumenata u prilog zaključka o održivosti postavke. Sofisti su otkrili i usavršili razložno mišljenje u njegovoj spontanoj dijalektici. ${ }^{5}$

U helenskoj kozmološkoj filozofiji iskazi o logosu su vodeće teorijske postavke u kojima se izlaže promišljanje metafizikalnih, fizikalnih i matematskih stvari. Pojam logosa nije se protezao na promišljanje ljudskog djelovanja. Sofisti su razumjeli da je ljudsko djelovanje u ontološkom smislu posebno. Razložnim mišljenjem tražili su ontološku strukturu djelovanja u razložnosti. Susret razložnog mišljenja djelovanja s razložnošću samoga djelovanja treba osigurati pouzdanu orijentaciju u djelovanju. Djelovanje može biti misaono i spoznatljivo, ako vlastite uzroke ima u sebi. Djelovanje je djelovanje ako je causa sui, ako je supstancijalno! Samo tako, ono se može ozbiljavati qua djelovanje, dakle, na zakonomjerni opći i nužni način, na uređen i uljuđen način! Ako je djelovanje takvo, moguće ga je normirati prema razložnim postavkama. Postavljanje i slijeđenje razložnih postavki zahtijeva navikavanje (ethos) na razložnost! Sofisti su Helene nagovarali na kulturu razložnog mišljenja. Tu su kulturu ujedno učinili - fillozofskim stanovištem. Prvi su otvorili mogućnost filozofskog traganja za dokazanim znanjem o djelovanju. Tako su otvorili mogućnost traženja jedinstva između misaonosti djelovanja i misaonosti ljudske svijesti o djelovanju. Djelovanje su htjeli osigurati razložnim mišljenjem i pribaviti mu obrazloženo važenje. Njihova namjera bila je izuzetno plodotvorna za razvoj filozofije i opće kulture mišljenja. Međutim, bila je razorna za ono što je htjela spasiti od krize i propadanja. To je kapitalna paradoksija sofističke filozofske i kulturne djelatnosti. Razložnošću su htjeli sačuvati ono što može važiti samo kao neobrazloženo! Moć razložne svijesti je paradoksalna zato što svaku postavku može potvrđivati i opovrgavati! Svaku postavku razlaganjem može razoriti ili učvrstiti nalaženjem dobrog, tj. dovoljnog razloga.

Traženje dovoljnog razloga može biti logička vježba. Djelatni život ljudi, naprotiv, počiva na živim interesima. Interesi nikad nisu u službi »čiste« logike. Tko ih ima, trudi se da ih logički opravda! Razložnost (rezoniranje) u djelatnom životu odlučuje pro et contra o stvarima koje su ljudima od životne važnosti. Neizbježno je da se logičko rasuđivanje stavlja u službu interesa lju- 
di. Razložnost može biti vođena dobrom namjerom, ali i samovoljom. Ljudi mogu htjeti stvari koje su od općeg interesa, ali i one koje su isključivo njima korisne, a drugima štetne. Tko je vješt u razložnom mišljenju, može za jedan ili drugi interes naći dovoljni razlog. Oni mogu biti suprotni, pa i sukobljeni. Sukob interesa vodi sukobu razloga te sukobu ljudi. Umjesto suglasnosti, razložnost može stvarati još veću nesuglasnost u stvarima djelovanja. Slično je i s odnosom prema važećim običajima i zakonima. Sofisti su dokazivali da oni nisu utemeljeni u poretku prirode, nego da odstupaju od prirodnog zakona ili tzv. prirodnog prava.

Sofisti su Helenima otkrili razložno mišljenje. Otkrili su i da djelovanje može zavisiti od namjera čovjeka. Rezultat te spoznaje je postignuće svijesti o samoj svijesti, tj. samosvijesti. Samosvijest je djelatna svijest koja je svjesna sebe kao djelatne svijesti! Bez samosvijesti nema ni djelovanja (praxis). Čovjek uvijek očituje spontanu svjesnu djelatnost prema vlastitoj ljudskosti i ljudskosti drugih ljudi. Kada ta spontanost postane tematskom, kada svijest postane svjesnom sebe, djelatnost postaje - djelovanjem (praksisom)! Djelovanja nema bez svijesti o djelovanju. Ljudi starih civilizacija imali su bogatu svjesnu djelatnost (u karakterima pojedinaca, u zakonodavnoj i državotvornoj djelatnosti, u ekonomskom poslovanju itd.). No prije helenske sofistike oni nisu imali samosvijest, tj. tematsku misaonu povratnu svijest o svojoj svjesnoj djelatnosti. Nastajanjem samosvijesti kod sofista stvorena je bitna pretpostavka za nastanak praktičke filozofije kao filozofije o ljudskom karakteru (ethos).

\title{
Milenko A. Perović
}

\section{Sophistic Proto-Ethics}

\begin{abstract}
In order to identify genesis of moral-ethical phenomenon, author starts from certainty of its historical, and not "eternal", character. Its rudimental form is found in proto-moral consciousness and proto-ethical philosophical standpoint of the Sophists. Resting upon Aristotle and Hegel, author reconstructs Hellenic system of ethical life (Sittlichkeit) and shows the meaning of historical turn the Sophists made within that system by their own philosophical and cultural mission. Within this turn, moral-ethical phenomenon was born as a product of sophistic confrontation of principle of reason (reasoning) with traditional representational consciousness.
\end{abstract}

Keywords

Sophists, ethical life, morals, ethics, representation, reason, reasoning

5

Razložno mišljenje započinje utvrđivanjem postavke. Ona je polazna točka promišljanja, ali i dokaz kao konačni cilj razložnosti. Drugi moment je argumentiranje izabrane postavke i pobijanje njenih protu-argumenata (instatia contraria). Treći moment je misaoni dokaz ili zaključak. U razložnosti se susreću analitička moć mišljenja, dijalektičko umijeće svestranog razmatranja predmeta (nalaženje argumenata pro et contra) te izvođenje jednog pojma iz drugog. 